\title{
Oxidation of formic acid on stepped Au(997) surface
}

\author{
Zong-Fang Wu, Zhi-Quan Jiang, Yue-Kang Jin, Feng Xiong, Guang-Hui Sun, Wei-Xin Huang * \\ Hefei National Laboratory for Physical Sciences at the Microscale, CAS Key Laboratory of Materials for Energy Conversion, Department of Chemical \\ Physics, University of Science and Technology of China, Hefei 230026, Anhui, China
}

\section{A R T I C L E I N F O}

\section{Article history:}

Received 11 April 2016

Accepted 16 May 2016

Published 5 October 2016

\section{Keywords:}

Gold catalysis

Surface chemistry

Model catalyst

Geometric structure

Coordination number

\begin{abstract}
A B S T R A C T
The adsorption and reaction of formic acid $(\mathrm{HCOOH})$ on clean and atomic oxygen-covered $\mathrm{Au}(997)$ surfaces were studied by temperature-programmed desorption/reaction spectroscopy (TPRS) and X-ray photoelectron spectroscopy (XPS). At 105 K, HCOOH molecularly adsorbs on clean Au(997) and interacts more strongly with low-coordinated $\mathrm{Au}$ atoms at (111) step sites than with those at (111) terrace sites. On an atomic oxygen-covered $\mathrm{Au}(997)$ surface, $\mathrm{HCOOH}$ reacts with oxygen atoms to form $\mathrm{HCOO}$ and $\mathrm{OH}$ at $105 \mathrm{~K}$. Upon subsequent heating, surface reactions occur among adsorbed $\mathrm{HCOO}, \mathrm{OH}$, and atomic oxygen and produce $\mathrm{CO}_{2}, \mathrm{H}_{2} \mathrm{O}$, and $\mathrm{HCOOH}$ between 250 and $400 \mathrm{~K}$. The Au(111) steps bind surface adsorbates more strongly than the Au(111) terraces and exhibit larger barriers for $\mathrm{HCOO}(\mathrm{a})$ oxidation reactions. The surface reactions also depend on the relative coverages of co-existing surface species. Our results elucidate the elementary surface reactions between formic acid and oxygen adatoms on Au surfaces and highlight the effects of the coordination number of the Au atoms on the Au catalysis.
\end{abstract}

(C) 2016, Dalian Institute of Chemical Physics, Chinese Academy of Sciences. Published by Elsevier B.V. All rights reserved.

\section{Introduction}

$\mathrm{HCOOH}$ is an important intermediate of many industrial catalytic reactions and also has great potential for use in $\mathrm{H}_{2}$ storage materials and fuel cells [1-7]. Thus, the adsorption and reaction of $\mathrm{HCOOH}$ on metal catalysts have been extensively studied [8-26]. $\mathrm{HCOOH}$ is very reactive on $\mathrm{W}(100)$ surfaces and completely dissociates to form $\mathrm{C}, \mathrm{O}$, and $\mathrm{H}$ [8], but undergoes partial dissociation on most transition metal surfaces to form either $\mathrm{CO}$ and $\mathrm{H}_{2} \mathrm{O}$ or $\mathrm{CO}_{2}$ and $\mathrm{H}_{2}$ [9-18]. The latter reaction pathway makes $\mathrm{HCOOH}$ a potential $\mathrm{H}_{2}$ storage material $[3,6,7]$. $\mathrm{HCOOH}$ molecularly adsorbs on coinage metal surfaces, such as $\mathrm{Au}$ and $\mathrm{Ag}[20-23,26]$. However, it has also been reported that $\mathrm{HCOOH}$ dissociates on $\mathrm{Au}$ and Ag surfaces with rich defects $[19,24]$.
$\mathrm{Au}$ catalysis has been one of the most fascinating topics in heterogeneous catalysis over the last three decades [27-29]. Supported Au catalysts have been reported to catalyze the decomposition of $\mathrm{HCOOH}$ to produce $\mathrm{H}_{2}$ [2-5]. Meanwhile, formate $(\mathrm{HCOO})$ or carboxylate $(\mathrm{COOH})$ species were proposed as the key intermediates in the low temperature oxidation of CO catalyzed by supported Au catalysts in the presence of moisture $[26,30]$. Thus, the surface chemistry of $\mathrm{HCOOH}$ on Au surfaces is of interest and importance. Model catalyst studies of well-defined $\mathrm{Au}$ surfaces have greatly advanced the fundamental understanding of Au catalysis [31,32]. For example, Chtaib and coworkers [19-21] compared the adsorption and reaction of $\mathrm{HCOOH}$ on Au foil, Au(111), and Au(110) surfaces. On Au foil, molecularly-adsorbed $\mathrm{HCOOH}$ dissociates upon heating, forming $\mathrm{HCOO}$ species on the surface and eventually producing $\mathrm{CO}_{2}$

\footnotetext{
* Corresponding author. Tel: +86-551-63600435; Fax: +86-551-63600437; E-mail: huangwx@ustc.edu.cn

This work was supported by the National Basic Research Program of China (973 Program, 2013CB933104), the National Natural Science Foundation of China (21525313, 20973161, 21373192), the Fundamental Research Funds for the Central Universities (WK2060030017), and Collaborative Innovation Center of Suzhou Nano Science and Technology.

DOI: 10.1016/S1872-2067(16)62467-1 | http://www.sciencedirect.com/science/journal/18722067 | Chin. J. Catal., Vol. 37, No. 10, October 2016
} 
and $\mathrm{H}_{2}$. On $\mathrm{Au}(110)$, $\mathrm{HCOOH}$ adsorbs as a $\mathrm{HCOOH}$ monomer through H-bond interaction. On $\mathrm{Au}(111)$, $\mathrm{HCOOH}$ adsorbs as $(\mathrm{HCOOH})_{2}$ dimers that dissociate into $\mathrm{HCOOOCH}$ surface species upon heating. A later study of the adsorption and reaction of $\mathrm{HCOOH}$ on clean and $\mathrm{H}_{2} \mathrm{O}$-covered $\mathrm{Au}(111)$ surfaces did not observe any dissociation [25]. HCOOH molecules were driven by $\mathrm{H}$ bonds to form $\mathrm{HCOOH}$ chains on $\mathrm{Au}(111)$. Upon heating, the H-bond network within the $\mathrm{HCOOH}$ chains was broken, and the adsorbed $\mathrm{HCOOH}$ formed $\mathrm{H}$-bonds with co-adsorbed $\mathrm{H}_{2} \mathrm{O}$. Study of the adsorption and reaction of $\mathrm{HCOOH}$ on atomic oxygen-covered $\mathrm{Au}(110)(\mathrm{O}(\mathrm{a}) / \mathrm{Au}(110))$ surface revealed a typical acid-basis reaction between $\mathrm{HCOOH}$ and $\mathrm{O}$ (a) to form $\mathrm{HCOO}$ and hydroxyl species [22]. The formate species underwent both the oxidation reaction to produce $\mathrm{CO}_{2}$ and $\mathrm{H}_{2} \mathrm{O}$ and the disproportionation reaction to produce $\mathrm{HCOOH}$. Another study of the adsorption and reaction of $\mathrm{HCOOH}$ on $\mathrm{O}(\mathrm{a}) / \mathrm{Au}(111)$ reported the formation of the HCOO species and its further decomposition [26].

Low coordinated $\mathrm{Au}$ atoms on supported $\mathrm{Au}$ particles have been demonstrated to play important roles in $\mathrm{Au}$ catalysis $[29,33,34]$ and can be modeled using stepped Au single crystal surfaces. In previous work, we used a stepped Au(997) surface with both (111) terraces with ninefold-coordinated $\mathrm{Au}$ atoms and (111) steps with sevenfold-coordinated Au atoms to compare the reactivity of $\mathrm{Au}$ atoms with the same coordination environment but different coordination number. The results revealed that $\mathrm{Au}$ atoms on (111) terraces and (111) steps exhibited different reactivity toward $\mathrm{NO}_{x}$ and $\mathrm{CO}_{x}$, and oxygen adatoms at different $\mathrm{Au}$ sites also exhibited different reactivity toward $\mathrm{NO}_{x}, \mathrm{CO}_{x}$, and $\mathrm{H}_{2} \mathrm{O}$ [35-39]. In the present paper, we report on the adsorption and reaction of $\mathrm{HCOOH}$ on clean and $\mathrm{O}(\mathrm{a})$-covered stepped $\mathrm{Au}(997)$ surfaces. The reaction pathways between $\mathrm{HCOOH}$ and $\mathrm{O}(\mathrm{a})$ were found to be sensitive to their relative coverages, and the (111) step sites were found to exhibit larger reaction barriers in catalyzing $\mathrm{HCOOH}$ oxidation than the (111) terrace sites.

\section{Experimental}

All experiments were performed in a Leybold stainless-steel ultra-high-vacuum (UHV) chamber with a base pressure of 1-2 $\times 10^{-10}$ mbar that has been described in detail elsewhere [39]. The UHV chamber was equipped with facilities for X-ray photoelectron spectroscopy (XPS), low energy electron diffraction (LEED), and differentially pumped thermal desorption spectroscopy (TDS) measurements. A Au(997) single crystal purchased from MaTeck was mounted on the sample holder using two Ta wires spot-welded to the back of the sample. The sample temperature, which was measured with a chromel-alumel thermocouple spot-welded to the back of the sample, could be controlled between 100 and $1273 \mathrm{~K}$. Prior to the experiments, the $\mathrm{Au}$ (997) surface was cleaned with repeated cycles of Ar ion sputtering and annealing at $800 \mathrm{~K}$ until a sharp LEED pattern was obtained and no contaminants could be detected by XPS. $\mathrm{NO}_{2}$ (>99.9\%, Nanjing Shang Yuan Industry Factory, China) was used as received. Formic acid (99.9\%, Sinopharm Chemical Reagent Co., China) and ultrapure water ( $>18 \mathrm{M} \Omega$ ) were puri- fied by repeated freeze-pump-thaw cycles. The purities of all reactants were checked by quadrupole mass spectrometry (QMS) prior to the experiments. All exposures are reported in Langmuir ( $\left.1 \mathrm{~L}=1.0 \times 10^{-6} \mathrm{Torr} \cdot \mathrm{s}\right)$ without correction for the gauge sensitivity. Line-of-sight stainless steel dosers (diameter: $8 \mathrm{~mm}$ ) positioned $\sim 2 \mathrm{~mm}$ in front of the $\mathrm{Au}(997)$ surface were used for the relatively large $\mathrm{NO}_{2}$ and $\mathrm{HCOOH}$ exposures to control the chamber pressure to below $5 \times 10^{-10}$ Torr. The reported exposures obtained with the line-of-sight stainless dosers were corrected according to the enhancement effect of the doser ( 1000) [40]. Oxygen adatoms were prepared on the $\mathrm{Au}(997)$ surface by thermal decomposition of amorphous $\mathrm{N}_{2} \mathrm{O}_{4}$ multilayers [39]. During the TDS experiments, the $\mathrm{Au}(997)$ surface was positioned $\sim 1 \mathrm{~mm}$ from the collecting tube of a differentially pumped QMS instrument and heated at a rate of $3.0 \mathrm{~K} / \mathrm{s}$. XPS spectra were taken with a pass energy of $20 \mathrm{eV}$ using $\mathrm{Al} K_{\alpha}$ radiation $(h v=1486.6 \mathrm{eV})$.

\section{Results and discussion}

Fig. 1(A) displays HCOOH TDS spectra obtained following various $\mathrm{HCOOH}$ exposures on clean $\mathrm{Au}(997)$ at $105 \mathrm{~K}$. At a HCOOH exposure of $0.01 \mathrm{~L}$, a tiny $\mathrm{HCOOH}$ desorption peak appeared at $190 \mathrm{~K}$. Increasing the $\mathrm{HCOOH}$ exposure to $0.05 \mathrm{~L}$ led to the saturation of this peak as well as the development of an additional $\mathrm{HCOOH}$ desorption peak at $170 \mathrm{~K}$. The desorption peak at $170 \mathrm{~K}$ grew in intensity without any shift in the peak temperature as the $\mathrm{HCOOH}$ exposure was increased to $10 \mathrm{~L}$, a characteristic of first order desorption kinetics. When the $\mathrm{HCOOH}$ exposure exceeded $10 \mathrm{~L}$, the desorption continued to grow with $\mathrm{HCOOH}$ exposure and the peak temperature shifted toward higher temperature, a characteristic of zero order desorption kinetics. A shoulder $\mathrm{HCOOH}$ desorption peak at $140 \mathrm{~K}$ was also observed at a $\mathrm{HCOOH}$ exposure of $20 \mathrm{~L}$ but did not change with further $\mathrm{HCOOH}$ exposure. No other desorption signals were observed except for the desorption traces of CO, $\mathrm{CO}_{2}$, and water originating from the background adsorption from the residual gas. Fig. 1(B) and (C) show the $\mathrm{C} 1 \mathrm{~s}$ and $\mathrm{O} 1 \mathrm{~s}$ XPS spectra obtained after various exposures of $\mathrm{HCOOH}$ on clean $\mathrm{Au}(997)$ at $105 \mathrm{~K}$, respectively. For $\mathrm{HCOOH}$ exposures below $10 \mathrm{~L}$, a single $\mathrm{C} 1 \mathrm{~s}$ component at $289.1 \mathrm{eV}$ and a single $\mathrm{O}$ $1 s$ component at $532.8 \mathrm{eV}$ were observed and could be assigned to the $\mathrm{C} 1 \mathrm{~s}$ and $\mathrm{O} 1 \mathrm{~s}$ signals of molecularly adsorbed HCOOH on the Au surface $[19,26]$. The different chemical environments of the two $\mathrm{O}$ atoms within molecular $\mathrm{HCOOH}$ led to the broad FWHM of the $01 s$ XPS spectrum $[17,19]$. Both peaks increased in intensity with $\mathrm{HCOOH}$ exposure without any binding energy shifts. When the $\mathrm{HCOOH}$ exposure reached $20 \mathrm{~L}$, both the C $1 s$ and $01 s$ XPS features broadened and shifted to higher binding energy. At a $\mathrm{HCOOH}$ exposure of $50 \mathrm{~L}$, the $\mathrm{C} 1 \mathrm{~s}$ and $01 s$ peaks were located at 290.1 and $533.6 \mathrm{eV}$, respectively, corresponding to those of $\mathrm{HCOOH}$ multilayers on metal surfaces $[19,26]$.

Fig. 2 shows the C $1 s$ and $01 s$ XPS spectra obtained after exposure of the $\mathrm{Au}(997)$ to $10 \mathrm{~L} \mathrm{HCOOH}$ at $105 \mathrm{~K}$ followed by annealing at different elevated temperatures. An exposure of $10 \mathrm{~L} \mathrm{HCOOH}$ at $105 \mathrm{~K}$ gave rise to a C $1 s$ XPS feature at $289 \mathrm{eV}$ 

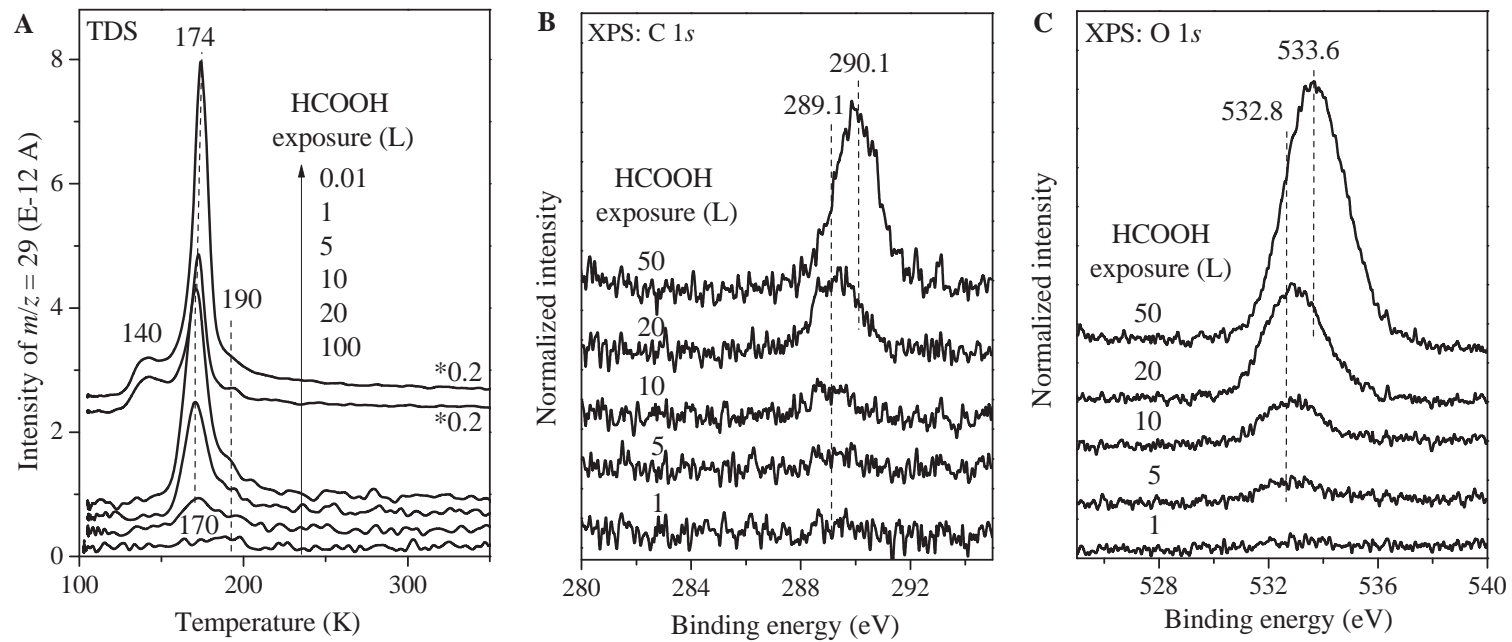

Fig. 1. $\mathrm{HCOOH}(m / z=29)$ TDS spectra (A), and C $1 s(\mathrm{~B})$ and $01 s(\mathrm{C})$ XPS spectra following various HCOOH exposures on clean Au(997) at 105 K.
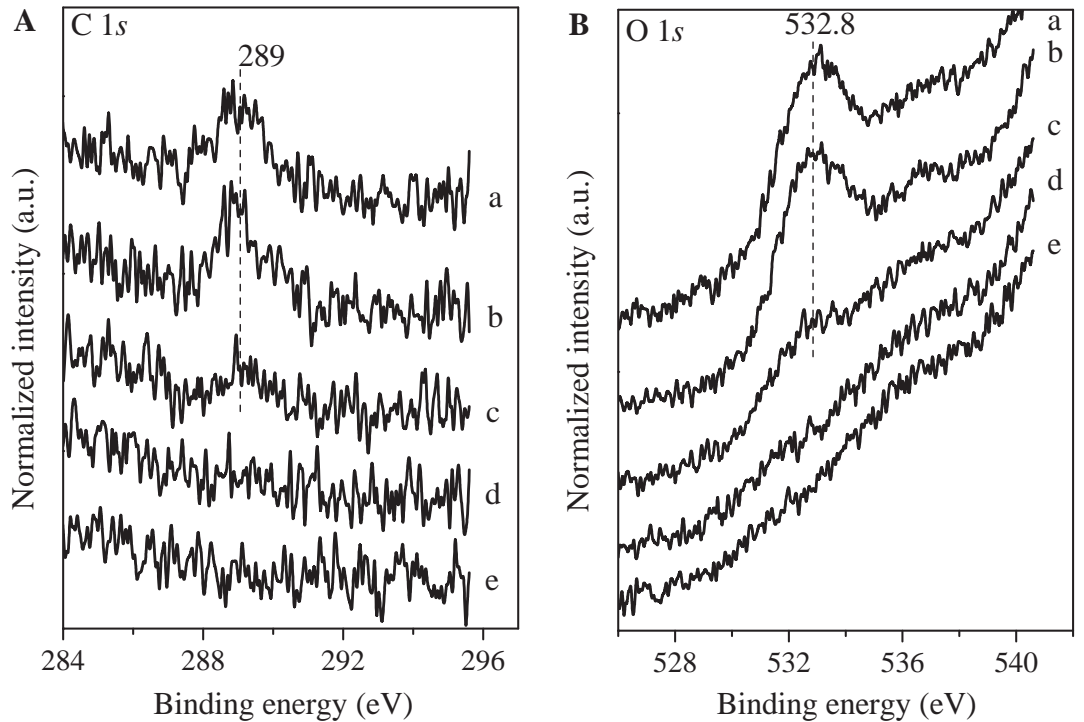

Fig. 2. C $1 s(\mathrm{~A})$ and $01 s$ (B) XPS spectra after exposure of Au(997) to $10 \mathrm{~L} \mathrm{HCOOH}$ at $105 \mathrm{~K}$ (a) followed by annealing at $145 \mathrm{~K}$ (b), $180 \mathrm{~K}$ (c), $220 \mathrm{~K}$ (d) and $700 \mathrm{~K}(\mathrm{e})$.

and an $01 s$ XPS feature at $532.8 \mathrm{eV}$. Neither feature changed much upon annealing at $145 \mathrm{~K}$, but both were greatly attenuated upon annealing at $180 \mathrm{~K}$ and completely vanished upon annealing at $220 \mathrm{~K}$, corresponding to the $\mathrm{HCOOH}$ desorption peaks at 170 and $190 \mathrm{~K}$ shown in the TDS results, respectively. No residual $\mathrm{C} 1 s$ and $01 s$ features were observed in the XPS spectra after annealing at $220 \mathrm{~K}$ or above, indicating the molecular desorption of the adsorbed $\mathrm{HCOOH}$ from the Au(997) surface.

The above TDS and XPS results demonstrate the reversible molecular adsorption of $\mathrm{HCOOH}$ on $\mathrm{Au}(997)$ at $105 \mathrm{~K}$. The HCOOH monolayer desorbed from the (111) steps and (111) terraces of the $\mathrm{Au}(997)$ surface at 190 and $170 \mathrm{~K}$, respectively. This agrees with previous observations of enhanced adsorption energies on low-coordinated Au atoms [29,31,38,39]. A HCOOH multilayer formed at $\mathrm{HCOOH}$ exposures exceeding $10 \mathrm{~L}$. Its desorption peak overlapped with that of $\mathrm{HCOOH}$ monolayer on the (111) terraces at $170 \mathrm{~K}$, resulting in a change from first order desorption kinetics to zero order desorption kinetics with increasing $\mathrm{HCOOH}$ exposure. This also indicates a weak interaction of $\mathrm{HCOOH}$ with the (111) terrace sites of $\mathrm{Au}(997)$ surface. The shoulder $\mathrm{HCOOH}$ desorption peak at $140 \mathrm{~K}$ appearing at large $\mathrm{HCOOH}$ exposures could be attributable to the desorption of $\mathrm{HCOOH}$ interacting via $\mathrm{H}$ bonding with co-adsorbed water from background water adsorption. A similar result has been reported in a previous study [25].

The adsorption and reaction of $\mathrm{HCOOH}$ on an $\mathrm{O}(\mathrm{a})$-covered $\mathrm{Au}(997)$ surface were then studied. Fig. 3 shows the temperature-programmed reaction spectroscopy (TPRS) spectra of various $m / z$ signals after exposure of $\mathrm{O}(\mathrm{a}) / \mathrm{Au}(997)$ surfaces with various coverages of $\mathrm{O}$ (a) to $0.5 \mathrm{~L} \mathrm{HCOOH}$ at $105 \mathrm{~K} .0 .02$ ML-O(a)/Au(997) with atomic oxygen at the (111) steps (peak denoted $\alpha$ in Fig. 3(E)), $0.12 \mathrm{ML}-\mathrm{O}(\mathrm{a}) / \mathrm{Au}(997)$ with atomic oxygen at both (111) steps and (111) terraces (peak denoted $\beta$ in Fig. 3(E)), and 0.26 ML-O(a)/Au(997) with atomic oxygen at both (111) steps and (111) terraces and $\mathrm{O}(\mathrm{a})$ islands on the 

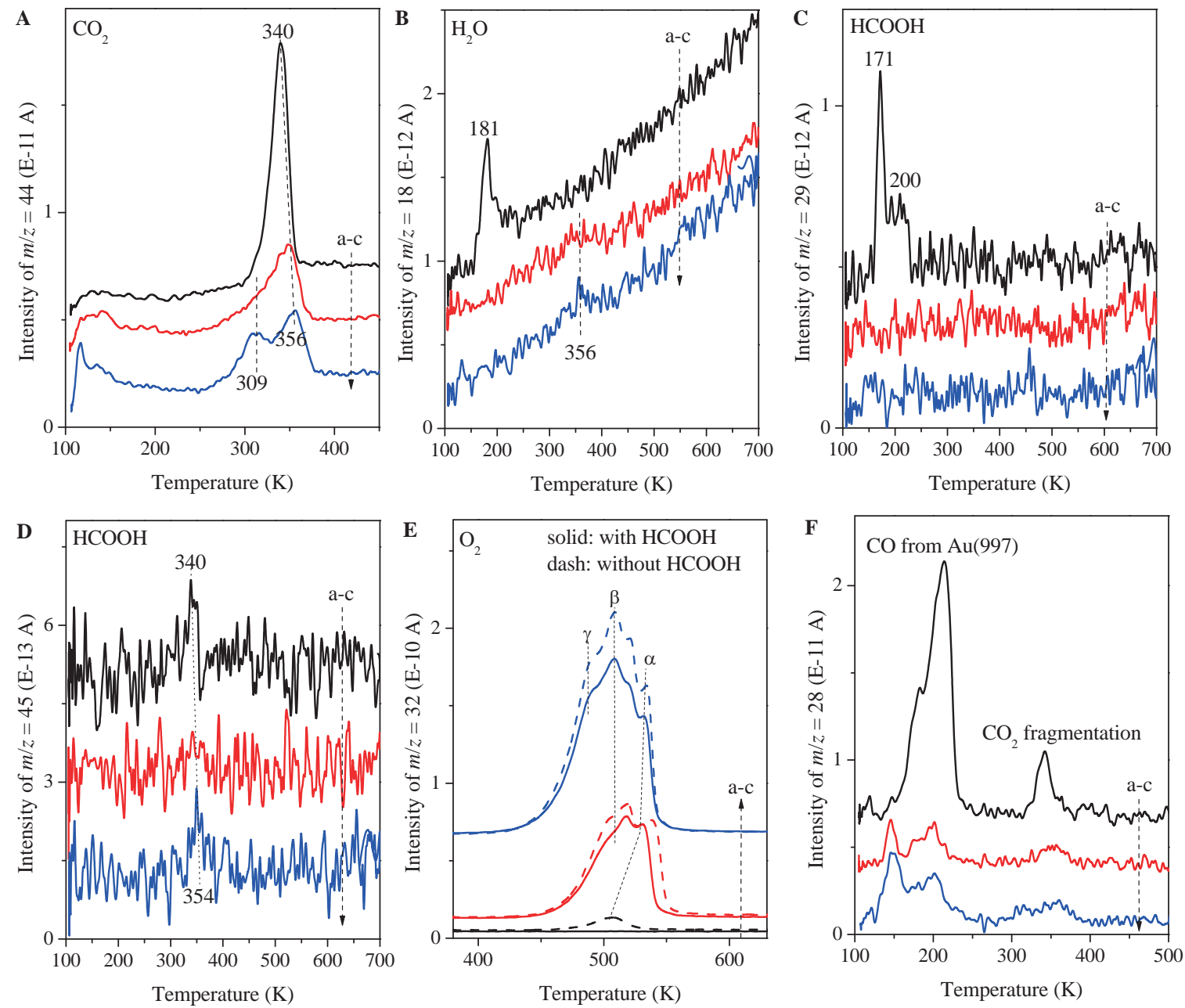

Fig. 3. $\mathrm{CO}_{2}(m / z=44)(\mathrm{A}), \mathrm{H}_{2} \mathrm{O}(m / z=18)(\mathrm{B}), \mathrm{HCOOH}(m / z=29)(\mathrm{C}), \mathrm{HCOOH}(m / z=45)(\mathrm{D}), \mathrm{O}_{2}(\mathrm{~m} / z=32)(\mathrm{E})$, and CO (m/z=28) (F) TDS spectra after an exposure of $0.5 \mathrm{~L} \mathrm{HCOOH}$ at $105 \mathrm{~K}$ on $0.02 \mathrm{ML}-\mathrm{O}(\mathrm{a}) / \mathrm{Au}(997)(\mathrm{a}), 0.12 \mathrm{ML}-\mathrm{O}(\mathrm{a}) / \mathrm{Au}(997)(\mathrm{b})$, and 0.26 ML O(a)/Au(997) (c) surfaces.

(111) terraces (peak denoted $\gamma$ in Fig. 3(E)) were reproducibly prepared by the thermal dissociation of different coverages of multilayer $\mathrm{N}_{2} \mathrm{O}_{4}$ [35-37,39]. As shown in Fig. 3(A), a sharp and strong $\mathrm{CO}_{2}$ desorption peak at $340 \mathrm{~K}$ appeared for the 0.02 ML-O(a)/Au(997) surface. This feature attenuated with increasing initial $\mathrm{O}(\mathrm{a})$ coverage, with the maximum shifting to higher temperature. Meanwhile, a shoulder $\mathrm{CO}_{2}$ desorption peak emerged at $309 \mathrm{~K}$ for the $0.12 \mathrm{ML}-\mathrm{O}(\mathrm{a}) / \mathrm{Au}(997)$ surface and was obviously larger for the $0.26 \mathrm{ML}-\mathrm{O}(\mathrm{a}) / \mathrm{Au}(997)$ surface. The $\mathrm{CO}_{2}$ desorption traces below $300 \mathrm{~K}$ originated from the oxidation of adsorbed $\mathrm{CO}$ from the residual gas with the pre-covered $\mathrm{O}(\mathrm{a})$ [35]. Fig. 3(B) displays the $\mathrm{H}_{2} \mathrm{O}$ TPRS spectra. A single $\mathrm{H}_{2} \mathrm{O}$ desorption peak appeared at $181 \mathrm{~K}$ for the 0.02 $\mathrm{ML}-\mathrm{O}(\mathrm{a}) / \mathrm{Au}(997)$ surface. In comparison with that observed in the $\mathrm{H}_{2} \mathrm{O}$ TDS spectra for clean $\mathrm{Au}$ (997) [37], this $\mathrm{H}_{2} \mathrm{O}$ desorption peak seemed to be reaction-controlled rather than desorption-controlled. However, $\mathrm{H}_{2} \mathrm{O}$ desorption traces appear simultaneously with those of $\mathrm{CO}_{2}$ for the 0.12 and 0.26 ML-O(a)/ $\mathrm{Au}(997)$ surfaces, suggesting that $\mathrm{CO}_{2}$ and $\mathrm{H}_{2} \mathrm{O}$ were produced from the same surface reaction.

Fig. 3(C) and (D) display HCOOH TPRS spectra with $m / z=$ 29 and 45, respectively. For the 0.02 ML-O(a)/Au(997) surface, the $m / z=29$ signal exhibited a main peak at $171 \mathrm{~K}$ and a shoulder peak at $200 \mathrm{~K}$, which arose from the molecular desorption of $\mathrm{HCOOH}$ on the (111) terraces and (111) steps of $\mathrm{Au}$ (997), respectively. However, no such signals were observed for the 0.12 and 0.26 ML-O(a)/Au(997) surfaces. These observations suggest that the adsorbed $\mathrm{HCOOH}$ completely reacted on the 0.12 and $0.26 \mathrm{ML}-\mathrm{O}(\mathrm{a}) / \mathrm{Au}(997)$ surfaces but not on the $0.02 \mathrm{ML}-\mathrm{O}(\mathrm{a}) / \mathrm{Au}(997)$ surface. However, the $m / z=45$ signal gave desorption traces that accompanied the corresponding $\mathrm{CO}_{2}$ desorption peaks for all $\mathrm{O}(\mathrm{a}) / \mathrm{Au}(997)$ surfaces, indicating that $\mathrm{HCOOH}$ was also formed in the surface reaction that produced $\mathrm{CO}_{2}$. It is noteworthy that the desorption traces of the signals with $m / z=29$ and 45 did not accompany each other. It was previously reported that molecularly-adsorbed $\mathrm{HCOOH}$ likely desorbed in the form of $\mathrm{HCOOH}$ dimers, while $\mathrm{HCOOH}$ produced by surface reaction desorbs in the form of $\mathrm{HCOOH}$ monomers [15], resulting in the different fragmentation patterns observed in the present TPRS results.

Fig. 3(E) shows the obtained $\mathrm{O}_{2}$ TPRS spectra. Corresponding $\mathrm{O}_{2}$-TDS spectra without $\mathrm{HCOOH}$ exposure are also included for comparison. In agreement with the $\mathrm{HCOOH}$ TPRS results, the pre-covered $\mathrm{O}(\mathrm{a})$ on the $0.02 \mathrm{ML}-\mathrm{O}(\mathrm{a}) / \mathrm{Au}(997)$ surface 
were completely consumed, while those on 0.12 and 0.26 ML-O(a)/Au(997) surfaces were not. We also monitored the $\mathrm{H}_{2}$ and CO TPRS spectra during the experiments. No $\mathrm{H}_{2}$ production was observed. CO desorption traces were observed (Fig. 3(F)), but the CO desorption peaks below $200 \mathrm{~K}$ originated from adsorbed $\mathrm{CO}$ on $\mathrm{Au}(997)$ owing to the background adsorption of $\mathrm{CO}$ while the $\mathrm{CO}$ desorption features above $300 \mathrm{~K}$ resulted from the fragmentation of $\mathrm{CO}_{2}$ in the QMS. Thus, no $\mathrm{CO}$ was produced following adsorption of $0.5 \mathrm{~L} \mathrm{HCOOH}$ on the O(a)/Au(997) surface.

The above results demonstrate the oxidation of $\mathrm{HCOOH}$ following the adsorption of $0.5 \mathrm{~L} \mathrm{HCOOH}$ on $\mathrm{O}(\mathrm{a}) / \mathrm{Au}(997)$ surfaces, but the extent of oxidation varied with the initial $\mathrm{O}(\mathrm{a})$ coverage. Molecularly-adsorbed $\mathrm{H}_{2} \mathrm{O}$ formed on the 0.02 ML-O(a)/Au(997) surface but not on the 0.12 and 0.26 ML-O(a)/Au(997) surfaces. The $\mathrm{CO}_{2}$ production peak at $\sim 350 \mathrm{~K}$ observed for all $\mathrm{O}(\mathrm{a}) / \mathrm{Au}(997)$ surfaces can be assigned to the oxidation of $\mathrm{HCOOH}$ by atomic $\mathrm{O}(\mathrm{a})$ at the (111) steps, while the $\mathrm{CO}_{2}$ production peak at $309 \mathrm{~K}$ observed for 0.12 and 0.26 ML-O(a)/Au(997) surfaces can be assigned to the oxidation of
HCOOH by $\mathrm{O}(\mathrm{a})$ species at the (111) terraces. This suggests that the reaction barrier of the oxidation of $\mathrm{HCOOH}$ into $\mathrm{CO}_{2}$ at the (111) step is slightly larger than that at the (111) terraces.

Fig. 4(A)-(E) display $\mathrm{CO}_{2}, \mathrm{H}_{2} \mathrm{O}, \mathrm{HCOOH}$, and $\mathrm{O}_{2}$ TPRS spectra measured following various $\mathrm{HCOOH}$ exposures on a 0.26ML-O(a)/Au(997) surface at $105 \mathrm{~K}$. At $0.5 \mathrm{~L} \mathrm{HCOOH}$ exposure, the oxidation of $\mathrm{HCOOH}$ on the (111) terrace sites and (111) step sites of the $\mathrm{Au}(997)$ surface produced $\mathrm{CO}_{2}, \mathrm{H}_{2} \mathrm{O}$, and $\mathrm{HCOOH}$ at 309 and $356 \mathrm{~K}$, respectively. The oxidation of $\mathrm{HCOOH}$ on the (111) terrace sites increased greatly with $\mathrm{HCOOH}$ exposure, resulting in rapid growth of the corresponding $\mathrm{CO}_{2}, \mathrm{H}_{2} \mathrm{O}$, and $\mathrm{HCOOH}$ desorption peaks and the shift of the maximum from 309 to $300 \mathrm{~K}$ (Fig. 4(A)-(D)), a typical characteristic of second-order desorption kinetics. This demonstrates that the $\mathrm{HCOOH}$ oxidation involved a bimolecular surface reaction. $\mathrm{CO}_{2}$ and $\mathrm{HCOOH}$ generation reached saturation at $5 \mathrm{~L}$ HCOOH exposure. Accordingly, the molecular desorption peaks of $\mathrm{HCOOH}$ from the (111) step and terrace sites appeared at 202 and 166 K, respectively (Fig. 4(C) and (D)). Again, the desorption of molecularly-adsorbed $\mathrm{HCOOH}$ and the desorption
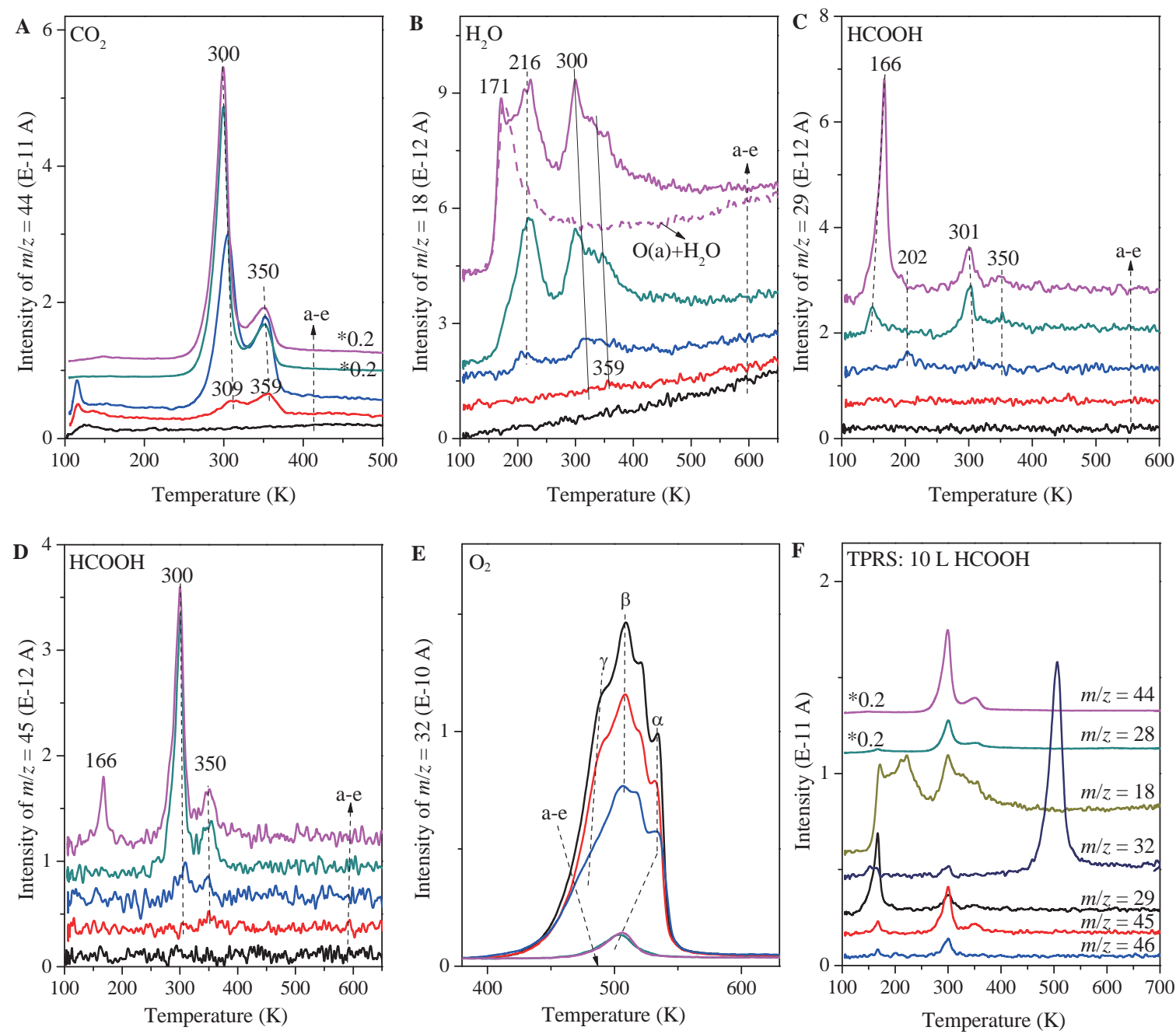

Fig. 4. $\mathrm{CO}_{2}(m / z=44)(\mathrm{A}), \mathrm{H}_{2} \mathrm{O}(\mathrm{m} / \mathrm{z}=18)(\mathrm{B}), \mathrm{HCOOH}(m / z=29)(\mathrm{C}), \mathrm{HCOOH}(m / z=45)$ (D), and $\mathrm{O}_{2}(\mathrm{~m} / \mathrm{z}=32)$ (E) TPRS spectra following exposure of $0.26 \mathrm{ML}-\mathrm{O}(\mathrm{a}) / \mathrm{Au}(997)$ surface to 0 (a), $0.5 \mathrm{~L}(\mathrm{~b}), 1 \mathrm{~L}$ (c), $5 \mathrm{~L}$ (d) and $10 \mathrm{~L}$ (e) $\mathrm{HCOOH}$ at $105 \mathrm{~K}$; (F) TPRS spectra of various $\mathrm{m} / z$ signals following exposure of the $0.26 \mathrm{ML}-\mathrm{O}(\mathrm{a}) / \mathrm{Au}(997)$ surface to $10 \mathrm{~L} \mathrm{HCOOH}$ at $105 \mathrm{~K}$. The trace of water desorption trace from $0.26 \mathrm{ML}-0(\mathrm{a}) / \mathrm{Au}(997)$ at $105 \mathrm{~K} \mathrm{is}$ also included for comparison. 
of reaction-formed $\mathrm{HCOOH}$ exhibited different fragmentation patterns for the signals of $m / z=29$ and 45 . The former exhibited a stronger $m / z=29$ signal, while the latter exhibited a stronger $m / z=45$ signal. In the water TPRS spectra (Fig. 4(B)), additional desorption peaks appeared and grew at 216 and 171 $\mathrm{K}$, and were respectively attributed to the recombination of surface hydroxyl groups and the desorption of O(a)-stabilized water on the $\mathrm{Au}$ (997) surface by comparing the water TDS spectra measured after water adsorption on a 0.26 ML-O(a)/Au(997) surface [37]. This demonstrates the increased formation of surface hydroxyl groups and water upon $\mathrm{HCOOH}$ oxidation after larger $\mathrm{HCOOH}$ exposures. The corresponding $\mathrm{O}_{2}$ TPRS spectra (Fig. 4(E)) show that the desorption peaks of all $\mathrm{O}(\mathrm{a})$ species attenuated with increasing $\mathrm{HCOOH}$ exposure, corresponding to the consumption of $\mathrm{O}(\mathrm{a})$ species owing to $\mathrm{HCOOH}$ oxidation. The consumption of various $\mathrm{O}(\mathrm{a})$ species followed the order of $\mathrm{O}(\mathrm{a})$ islands on the (111) terraces $>$ atomic oxygen at the (111) terraces $>$ atomic oxygen at the (111) steps. Furthermore, only atomic O(a) on the (111) steps remained on the surface after exposures of 5 and $10 \mathrm{~L} \mathrm{HCOOH}$. Fig. 4(F) compares the TPRS spectra of various signals measured after exposure of the $0.26 \mathrm{ML}-\mathrm{O}(\mathrm{a}) / \mathrm{Au}(997)$ surface to 10 $\mathrm{L} \mathrm{HCOOH}$ at $105 \mathrm{~K}$. It is clear that the $\mathrm{HCOOH}$ oxidation involved four surface reactions producing water at $175 \mathrm{~K}$, water at $219 \mathrm{~K}$, water, $\mathrm{CO}_{2}$, and $\mathrm{HCOOH}$ at $300 \mathrm{~K}$, and water, $\mathrm{CO}_{2}$, and $\mathrm{HCOOH}$ at $356 \mathrm{~K}$.

XPS was used to monitor the surface species of $\mathrm{HCOOH}$ oxidation on $\mathrm{O}(\mathrm{a}) / \mathrm{Au}(997)$ surfaces. Fig. 5 shows $\mathrm{C} 1 \mathrm{~s}$ and $\mathrm{O} 1 \mathrm{~s}$ XPS spectra obtained after exposing 0.26 ML-O(a)/Au(997) to $10 \mathrm{~L} \mathrm{HCOOH}$ following by annealing at elevated temperature. On a clean $\mathrm{Au}(997)$ surface, 0.26 ML O(a) produced an $01 \mathrm{~s}$ peak at $529.3 \mathrm{eV}$, while the adsorption of $10 \mathrm{~L} \mathrm{HCOOH}$ produced $\mathrm{C} 1 s$ and $01 s$ peaks at 289 and $532.8 \mathrm{eV}$, respectively. In the $\mathrm{C} 1 s$ XPS spectra (Fig. 5(A)), the $10 \mathrm{~L} \mathrm{HCOOH}$ exposure at $105 \mathrm{~K}$ led to a broad $\mathrm{C} 1 \mathrm{~s}$ spectrum in which a main component at $288.6 \mathrm{eV}$ and a shoulder feature at $287 \mathrm{eV}$ were identified. In the corresponding $01 s$ spectrum (Fig. 5(B)), the $\mathrm{O}(\mathrm{a})$ peak almost vanished and a broad $01 s$ feature appeared at $531.2 \mathrm{eV}$. Upon annealing at $145 \mathrm{~K}$, the $\mathrm{C} 1 \mathrm{~s}$ component at $287 \mathrm{eV}$ grew at the expense of that at $288.6 \mathrm{eV}$; accordingly, the low-binding energy part of the broad $01 s$ peak grew at the expense of the high-binding energy part, and three $01 s$ components at 530.7, 531.2, and $532.8 \mathrm{eV}$ were distinguished. The $\mathrm{C} 1 s$ component at $288.6 \mathrm{eV}$ almost vanished upon annealing at $180 \mathrm{~K}$, while the $\mathrm{C}$ $1 s$ component at $287 \mathrm{eV}$ did not change much upon annealing up to $220 \mathrm{~K}$, weakened upon annealing at $270 \mathrm{~K}$, and disappeared upon annealing at $300 \mathrm{~K}$. The $01 s$ component at 532.8 $\mathrm{eV}$ almost disappeared upon annealing at $180 \mathrm{~K}$, the $01 \mathrm{~s}$ component at $531.2 \mathrm{eV}$ attenuated upon annealing at $180 \mathrm{~K}$ and vanished upon annealing at $220 \mathrm{~K}$, and the 01 s component at $530.7 \mathrm{eV}$ shifted to $530.2 \mathrm{eV}$ upon annealing at $220 \mathrm{~K}$ owing to the disappearance of adsorbates, weakened upon annealing at $270 \mathrm{~K}$, and disappeared upon annealing at $300 \mathrm{~K}$.

Previous XPS results showed that the difference between the $\mathrm{C} 1 \mathrm{~s}$ binding energy of adsorbed $\mathrm{HCOOH}$ and $\mathrm{HCOO}$ varied between 1.0-1.3 eV [19,26], thus we assign the C 1 s peaks at 288.6 and $287 \mathrm{eV}$ to adsorbed $\mathrm{HCOOH}$ and $\mathrm{HCOO}$, respectively. Correspondingly, the $01 s$ components at 532.8, 531.2, and $530.7 / 530.2 \mathrm{eV}$ should respectively arise from molecularly adsorbed $\mathrm{HCOOH}$, hydroxyl groups, and HCOO. Thus the binding energies of adsorbed $\mathrm{HCOOH}$ and $\mathrm{HCOO}$ on $\mathrm{Au}(997)$ were easily affected by the co-adsorbates. The XPS results demonstrate that the reaction of $\mathrm{HCOOH}+\mathrm{O}$ (a) already occurs upon $\mathrm{HCOOH}$ exposure on $0.26 \mathrm{ML}-\mathrm{O}(\mathrm{a}) / \mathrm{Au}(997)$ at $105 \mathrm{~K}$ to produce $\mathrm{HCOO}$ and $\mathrm{OH}$ and further occurs upon annealing at $145 \mathrm{~K}$. The disappearance of the $\mathrm{HCOOH}$ component at 288.6 and $532.8 \mathrm{eV}$ upon annealing at $180 \mathrm{~K}$ corresponded to the desorption peak of molecularly-adsorbed $\mathrm{HCOOH}$ from the surface at $166 \mathrm{~K}$ in the corresponding TPRS spectrum. The attenuation upon annealing at $180 \mathrm{~K}$ and disappearance upon annealing at
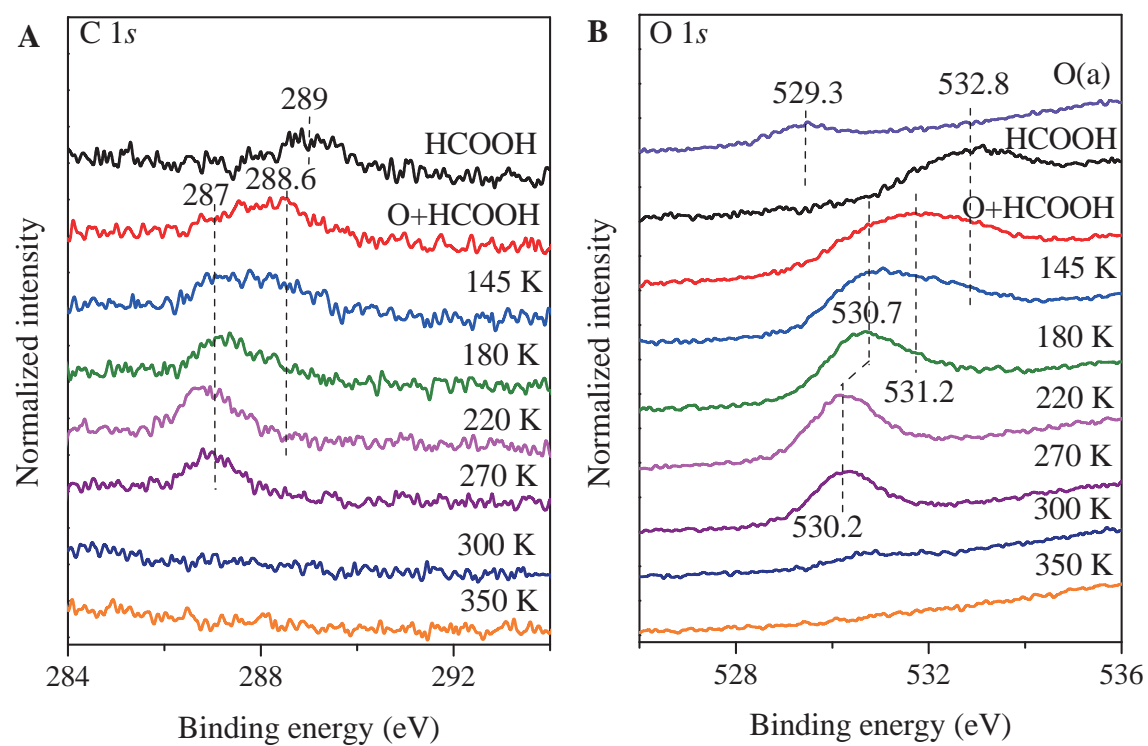

Fig. 5. C $1 s(\mathrm{~A})$ and $01 s$ (B) XPS spectra after exposure of $0.26 \mathrm{ML}-\mathrm{O}(\mathrm{a}) / \mathrm{Au}(997)$ surface to $10 \mathrm{~L} \mathrm{HCOOH}$ at $105 \mathrm{~K}$ followed by annealing at elevated temperature. The $\mathrm{C} 1 s$ XPS spectrum of $10 \mathrm{~L} \mathrm{HCOOH}$ on Au(997) and the 0 1s XPS spectrum of 0.26 ML-O(a)/Au(997) are also included for comparison. 
$220 \mathrm{~K}$ of the $\mathrm{OH}$ peak at $531.2 \mathrm{eV}$ corresponded to the water desorption peaks at 171 and $216 \mathrm{~K}$ in the TPRS spectrum. The disappearance of the HCOO feature at 287 and 530.7/530.2 eV upon annealing at $300 \mathrm{~K}$ corresponded to the further oxidation of $\mathrm{HCOO}$ on the surface to produce water, $\mathrm{CO}_{2}$, and $\mathrm{HCOOH}$ initiated above $250 \mathrm{~K}$ in the TPRS spectrum.

Thus, our TPRS and XPS results demonstrate that $\mathrm{O}(\mathrm{a})$ on $\mathrm{Au}(997)$ facilely abstracts the acidic $\mathrm{H}$ of $\mathrm{HCOOH}$ to form $\mathrm{HCOO}$ and $\mathrm{OH}$ at $105 \mathrm{~K}$, but the subsequent surface reactions depend both on the coordination number of $\mathrm{Au}$ sites and on the relative coverages of $\mathrm{O}(\mathrm{a})$ and $\mathrm{HCOO}$.

For 0.5 L HCOOH oxidation on 0.02 ML-O(a)/Au(997) with atomic oxygen on the (111) steps with sevenfold-coordinated $\mathrm{Au}$ atoms (Fig. 3), O(a) is completely consumed, and the coadsorbed surface species are $\mathrm{HCOO}(\mathrm{a}), \mathrm{OH}(\mathrm{a})$ and $\mathrm{HCOOH}(\mathrm{a})$. The reaction products are $\mathrm{H}_{2} \mathrm{O}$ at $181 \mathrm{~K}$ and $\mathrm{CO}_{2}$ and $\mathrm{HCOOH}$ at 340 $\mathrm{K}$. The surface reaction pathways are proposed to be as follows:

$$
\begin{array}{ll}
T=181 \mathrm{~K}: & \mathrm{HCOOH}(\mathrm{a})+\mathrm{OH}(\mathrm{a})=\mathrm{H}_{2} \mathrm{O}+\mathrm{HCOO}(\mathrm{a}) \\
T=340 \mathrm{~K}: & 2 \mathrm{HCOO}(\mathrm{a})=\mathrm{CO}_{2}+\mathrm{HCOOH}
\end{array}
$$

For $0.5 \mathrm{~L}$ HCOOH oxidation on $0.12 \mathrm{ML}$ and 0.26 ML-O(a)/Au(997) surfaces with oxygen species on both the (111) steps with sevenfold-coordinated $\mathrm{Au}$ atoms and the (111) terraces with ninefold-coordinated $\mathrm{Au}$ atoms (Fig. 3), $\mathrm{HCOOH}$ is completely consumed and co-adsorbed surface species are $\mathrm{HCOO}(\mathrm{a}), \mathrm{OH}(\mathrm{a})$ and $\mathrm{O}(\mathrm{a})$. The reaction products are simultaneous $\mathrm{H}_{2} \mathrm{O}, \mathrm{CO}_{2}$ and $\mathrm{HCOOH}$ at $309 \mathrm{~K}$ from the (111) terraces and at $356 \mathrm{~K}$ from the (111) steps. The surface reaction pathways are proposed as follows:

$$
\begin{gathered}
2 \mathrm{HCOO}(\mathrm{a})+\mathrm{O}(\mathrm{a})=\mathrm{H}_{2} \mathrm{O}+2 \mathrm{CO}_{2} \\
2 \mathrm{HCOO}(\mathrm{a})=\mathrm{CO}_{2}+\mathrm{HCOOH}
\end{gathered}
$$

For 10 L HCOOH oxidation on 0.26 ML-O(a)/Au(997) surfaces with oxygen species on both the (111) steps with sevenfold-coordinated $\mathrm{Au}$ atoms and the (111) terraces with ninefold-coordinated Au atoms (Fig. 4), none of the $\mathrm{HCOOH}$ or O(a) is completely consumed and the coadsorbed surface species are $\mathrm{HCOOH}(\mathrm{a}), \mathrm{HCOO}(\mathrm{a}), \mathrm{OH}(\mathrm{a})$, and $\mathrm{O}(\mathrm{a})$. Besides the surface reactions producing $\mathrm{H}_{2} \mathrm{O}, \mathrm{CO}_{2}$, and $\mathrm{HCOOH}$ at $309 \mathrm{~K}$ from the (111) terraces and at $356 \mathrm{~K}$ from the (111) steps, surface reactions also occur to produce water at 171 and $216 \mathrm{~K}$ following the proposed pathways:

$$
\begin{array}{ll}
T=171 \mathrm{~K}: & \mathrm{HCOOH}(\mathrm{a})+\mathrm{OH}(\mathrm{a})=\mathrm{H}_{2} \mathrm{O}+\mathrm{HCOO}(\mathrm{a}) \\
T=216 \mathrm{~K}: & \mathrm{OH}(\mathrm{a})+\mathrm{OH}(\mathrm{a})=\mathrm{H}_{2} \mathrm{O}+\mathrm{O}(\mathrm{a})
\end{array}
$$

Demonstrated by the reaction-controlled desorption temperatures of the reaction products (Figs. 3 and 4), the reaction barriers of all surface oxidation reactions of $\mathrm{HCOO}(\mathrm{a})$ into $\mathrm{CO}_{2}$, including $\mathrm{HCOO}(\mathrm{a})+\mathrm{O}(\mathrm{a})$ and $\mathrm{HCOO}(\mathrm{a})+\mathrm{HCOO}(\mathrm{a})$, at the (111) steps are slightly larger than at the (111) terraces. Meanwhile, the occurrence of $\operatorname{HCOO}(\mathrm{a})+\mathrm{O}(\mathrm{a})$ and $\mathrm{HCOO}(\mathrm{a})+\mathrm{HCOO}(\mathrm{a})$ at either step sites or terrace sites at the same temperature indicates that both surface reactions should have a common rate-limiting elementary surface reaction. This should be the $\mathrm{C}-\mathrm{H}$ bond rupture of $\mathrm{HCOO}(\mathrm{a})$ on the Au surface. Thus, the $\mathrm{Au}(111)$ steps bind HCOO(a) more strongly than the Au(111) terraces and exhibit a larger barrier for the $\mathrm{C}-\mathrm{H}$ bond rupture of HCOO(a). These observations demonstrate that surface species that bind with the Au surface more weakly are more reactive. Similar results were previously observed for $\mathrm{CO}+\mathrm{O}(\mathrm{a})$ and
NO + O(a) reactions on Au(997) surfaces, in which both surface reactions proceed with a larger barriers at the (111) steps than at the (111) terraces, in agreement with our previous results $[35,36]$. This also rationalizes the different relative consumptions of various oxygen species during $\mathrm{HCOOH}$ oxidation shown in Fig. 4. The $\mathrm{H}$ species resulting from the decomposition of HCOO(a) at the (111) steps should be lower in amount than at the (111) terraces owing to the higher decomposition barrier, and subsequently the amount of atomic oxygen at the (111) steps consumed by the water formation is lower than that at the (111) terraces.

\section{Conclusions}

Using a stepped $\mathrm{Au}(997)$ surface consisting of (111) terraces and (111) steps, we have successfully elucidated the surface reactions of $\mathrm{HCOOH}$ oxidation on an $\mathrm{Au}$ surface. O(a) on $\mathrm{Au}$ (997) facilely abstracts the acidic $\mathrm{H}$ of $\mathrm{HCOOH}$ to form $\mathrm{HCOO}(\mathrm{a})$ and $\mathrm{OH}$ at $105 \mathrm{~K}$. Upon subsequent heating, surface reactions among adsorbed $\mathrm{HCOO}(\mathrm{a}), \mathrm{OH}$, and atomic oxygen produce $\mathrm{CO}_{2}, \mathrm{H}_{2} \mathrm{O}$, and $\mathrm{HCOOH}$ between 250 and $400 \mathrm{~K}$. The $\mathrm{Au}(111)$ steps bind surface adsorbates more strongly than the $\mathrm{Au}(111)$ terraces and exhibit larger barriers for the HCOO(a) oxidation reactions. Depending on the relative coverages of surface species, the generation of water by the reaction between $\mathrm{HCOOH}(\mathrm{a})$ and $\mathrm{OH}(\mathrm{a})$ and by the reaction between $\mathrm{OH}(\mathrm{a})$ at low temperature also occurs. These results deepen the fundamental understanding of $\mathrm{HCOOH}$-involving reactions on $\mathrm{Au}$-based catalysts and highlight the effects of the coordination number of Au atoms on the Au catalysis.

\section{References}

[1] M. Shekhar, J. Wang, W. S. Lee, W. D. Williams, S. M. Kim, E. A. Stach, J. T. Miller, W. N. Delgass, F. H. Ribeiro, J. Am. Chem. Soc., 2012, 134, 4700-4708.

[2] Q. Y. Bi, X. L. Du, Y. M. Liu, Y. Cao, H. Y. He, K. N. Fan, J. Am. Chem. Soc., 2012, 134, 8926-8933.

[3] A. Gazsi, T. Bánsági, F. Solymosi, J. Phys. Chem. C, 2011, 115, 15459-15466.

[4] S. D. Senanayake, D. Stacchiola, J. Evans, M. Estrella, L. Barrio, M. Pérez, J. Hrbek, J. A. Rodriguez, J. Catal., 2010, 271, 392-400.

[5] S. S. Li, L. Tao, Q. Zhang, Y. M. Liu, Y. Cao, Acta Phys.-Chim. Sin., 2016, 32, 61-74.

[6] A. Boddien, B. Loges, F. Gärtner, C. Torborg, K. Fumino, H. Junge, R. Ludwig, M. Beller, J. Am. Chem. Soc., 2010, 132, 8924-8934.

[7] C. Fellay, P. J. Dyson, G. Laurenczy, Angew. Chem. Int. Ed., 2008, 47, 3966-3968.

[8] A. K. Bhattacharya, Surf. Sci., 1979, 79, L341-L345.

[9] L. A. Larson, J. T. Dickinson, Surf. Sci., 1979, 84, 17-30.

[10] N. R. Avery, Appl. Surf. Sci., 1982, 11-12, 774-783.

[11] S. L. Miles, S. L. Bernasek, J. L. Gland, Surf. Sci., 1983, 127, 271-282.

[12] C. Egawa, I. Doi, S. Naito, K. Tamaru, Surf. Sci., 1986, 176, 491-504.

[13] F. Solymosi, J. Kiss, I. Kovács, Surf. Sci., 1987, 192, 47-65.

[14] F. C. Henn, J. A. Rodriguez, C. T. Campbell, Surf. Sci., 1990, 236, 282-312.

[15] M. R. Columbia, A. M. Crabtree, P. A. Thiel, Surf. Sci., 1992, 271, 139-148.

[16] T. Ohtani, J. Kubota, A. Wada, J. N. Kondo, K. Domen, C. Hirose, Surf. 


\title{
Graphical Abstract
}

Chin. J. Catal., 2016, 37: 1738-1746 doi: 10.1016/S1872-2067(16)62467-1

\section{Oxidation of formic acid on stepped Au(997) surface}

Zong-Fang Wu, Zhi-Quan Jiang, Yue-Kang Jin, Feng Xiong, Guang-Hui Sun, Wei-Xin Huang *

University of Science and Technology of China

On the stepped Au(997) surface, (111) steps exhibit a larger activation energy than (111) terraces in catalyzing the oxidation of formic acid with atomic oxygen via formate and hydroxyl intermediates.
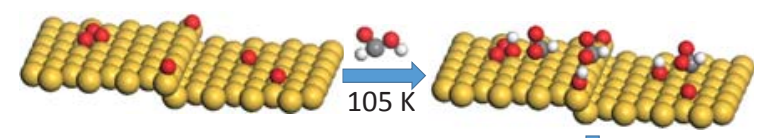

용
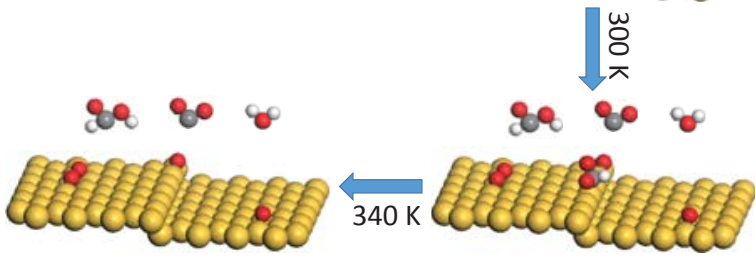

Sci., 1996, 368, 270-274.

[17] P. Stone, S. Poulston, R. A. Bennett, N. J. Price, M. Bowker, Surf. Sci, 1998, 418, 71-83.

[18] C. L. Hsu, E. F. McCullen, R. G. Tobin, Chem. Phys. Lett., 2000, 316, 336-342.

[19] M. Chtaib, J. P. Delrue, R. Caudano, Phys. Scrip., 1983, T4, 133-137.

[20] M. Chtaib, P. A. Thiry, J. P. Delrue, J. J. Pireaux, R. Caudano, J. Electron. Spectrosc. Relat. Phenom., 1983, 29, 293-299.

[21] M. Chtaib, P. A. Thiry, J. J. Pireaux, J. P. Delrue, R. Caudano, Surf. Sci, 1985, 162, 245-251.

[22] D. A. Outka, R. J. Madix, Surf. Sci., 1987, 179, 361-376.

[23] L. E. Fleck, Z. C. Ying, M. Feehery, H. L. Dai, Surf. Sci., 1993, 296, 400-409.

[24] G. J. Millar, J. B. Metson, G. A. Bowmaker, R. P. Cooney, J. Catal, 1994, 147, 404-416.

[25] M. Kazempoor, G. Pirug, Appl. Phys. A, 2007, 87, 435-441.

[26] S. D. Senanayake, D. Stacchiola, P. Liu, C. B. Mullins, J. Hrbek, J. A. Rodriguez, J. Phys. Chem. C, 2009, 113, 19536-19544.

[27] M. Haruta, T. Kobayashi, H. Sano, N. Yamada, Chem. Lett., 1987, 405-408.

[28] T. Takei, T. Akita, I. Nakamura, T. Fujitani, M. Okumura, K. Okazaki, J. Huang, T. Ishida, M. Haruta, Adv. Catal., 2012, 55, 1-126.
[29] W. X. Huang, K. Qian, Z. F. Wu, S. L. Chen, Acta Phys.-Chim. Sin., 2016, 32, 48-60.

[30] M. Daté, M. Okumura, S. Tsubota, M. Haruta, Angew. Chem. Int. Ed., 2004, 43, 2129-2132.

[31] J. L. Gong, Chem. Rev. 2011, 112, 2987-3054.

[32] R. Meyer, C. Lemire, S. K. Shaikhutdinov, H. J. Freund, Gold Bull,, 2004, 37, 72-124.

[33] N. Lopez, T. V. W. Janssens, B. S. Clausen, Y. Xu, M. Mavrikakis, T. Bligaard, J. K. Nørskov, J. Catal., 2004, 223, 232-235.

[34] K. Qian, L. F. Luo, H. Z. Bao, Q. Hua, Z. Q. Jiang, W. X. Huang, Catal. Sci. Technol., 2013, 3, 679-687.

[35] Z. F. Wu, Z. Q. Jiang, Y. K. Jin, F. Xiong, G. H. Sun, W. X. Huang, Sci. China Chem., 2016, Doi: 10.1007/s11426-015-5510-y.

[36] Z. F. Wu, Y. K. Jin, L. S. Xu, Q. Yuan, F. Xiong, Z. Q. Jiang, W. X. Huang, J. Phys. Chem. C, 2014, 118, 8397-8405.

[37] Z. F. Wu, Z. Q. Jiang, Y. K. Jin, F. Xiong, W. X. Huang, J. Phys. Chem. C, 2014, 118, 26258-26263.

[38] Z. F. Wu, L. S. Xu, W. H. Zhang, Y. S. Ma, Q. Yuan, Y. K. Jin, J. L. Yang, W. X. Huang, J. Catal., 2013, 304, 112-122.

[39] Z. F. Wu, Y. S. Ma, Y. L. Zhang, L. S. Xu, B. H. Chen, Q. Yuan, W. X. Huang, J. Phys. Chem. C, 2012, 116, 3608-3617.

[40] L. S. Xu, Y. S. Ma, Y. L. Zhang, B. H. Chen, Z. F. Wu, Z. Q. Jiang, W. X. Huang, J. Phys. Chem. C, 2010, 114, 17023-17029.

\section{甲酸在 $\mathrm{Au}(997)$ 台阶表面的氧化反应}

\author{
邬宗芳, 姜志全, 金岳康, 熊 锋, 孙光辉, 黄伟新
}

中国科学技术大学微尺度物质科学国家实验室(筹), 能量转换材料中国科学院重点实验室和化学物理系, 安徽合肥230026

摘要: 金催化是纳米催化的代表性体系之一, 但对金催化作用的理解还存在争议,特别是金颗粒尺寸对其催化作用的影响. 金颗粒尺寸减小导致的表面结构主要变化之一是表面配位不饱和金原子密度的增加, 因此研究金原子配位结构对其催化 作用的影响对于理解金催化作用尺寸依赖性具有重要意义. 具有不同配位结构的金颗粒表面可以利用金台阶单晶表面来 模拟. 我们研究组以同时具有 $\mathrm{Au}(111)$ 平台和 $\mathrm{Au}(111)$ 台阶的 $\mathrm{Au}(997)$ 台阶表面为模型表面, 发现 $\mathrm{Au}(111)$ 台阶原子在CO氧 化、NO氧化和 NO分解反应中表现出与 $\mathrm{Au}(111)$ 平台原子不同的催化性能.

负载型Au颗粒催化甲酸氧化反应是重要的Au催化反应之一. 本文利用程序升温脱附/反应谱(TDS/TPRS)和X射线光电 子能谱(XPS)研究了甲酸在清洁的和原子氧覆盖的 $\mathrm{Au}(997)$ 表面的吸附和氧化反应, 观察到 $\mathrm{Au}(111)$ 台阶原子和 $\mathrm{Au}(111)$ 平台 原子不同的催化甲酸根氧化反应行为. 与甲酸根强相互作用的 $\mathrm{Au}(111)$ 台阶原子表现出比与甲酸根弱相互作用的 $\mathrm{Au}(111)$ 平台原子更高的催化甲酸根与原子氧发生氧化反应的反应活化能.

在清洁 $\mathrm{Au}(997)$ 表面, 甲酸分子发生可逆的分子吸附和脱附. 甲酸分子在 $\mathrm{Au}(111)$ 台阶原子的吸附强于在 $\mathrm{Au}(111)$ 平台原 子的吸附. TDS结果表明, 吸附在 $\mathrm{Au}(111)$ 台阶原子的甲酸分子的脱附温度在 $190 \mathrm{~K}$, 吸附在 $\mathrm{Au}(111)$ 平台原子的甲酸分子的 
脱附温度在 $170 \mathrm{~K}$. XPS结果表明, 分子吸附甲酸的C $1 s$ 和O $1 s$ 结合能分别位于 289.1 和 $532.8 \mathrm{eV}$.

利用多层 $\mathrm{NO}_{2}$ 的分解反应在 $\mathrm{Au}(997)$ 表面控制制备具有不同原子氧吸附位和覆盖度的原子氧覆盖 $\mathrm{Au}(997)$ 表面, 包括氧 原子吸附在(111)台阶位的0.02 ML-O(a)/Au(997)、氧原子同时吸附在(111)台阶位和(111)平台位的0.12 ML-O(a)/Au(997)、 氧原子和氧岛吸附在(111)平台位和氧原子吸附在(111)台阶位的0.26 ML-O(a)/Au(997). TPRS和XPS结果表明, 甲酸分子在 $105 \mathrm{~K}$ 与 $\mathrm{Au}(997)$ 表面原子氧物种反应生成甲酸根和羟基物种, 但甲酸根物种的进一步氧化反应依赖于 $\mathrm{Au}$ 原子配位结构和 各种表面物种的相对覆盖度.

在0.02 ML-O(a)/Au(997)表面暴露0.5 L 甲酸时, $\mathrm{Au}(111)$ 台阶位氧原子完全反应, 甲酸过量. 表面物种是 $\mathrm{Au}(111)$ 台阶位 吸附的甲酸根、羟基和甲酸分子. 在加热过程中, 甲酸分子与羟基在 $181 \mathrm{~K}$ 反应生成甲酸根和气相水分子 $(\mathrm{HCOOH}(\mathrm{a})+$ $\mathrm{OH}(\mathrm{a})=\mathrm{H}_{2} \mathrm{O}+\mathrm{HCOO}(\mathrm{a})$ ), 甲酸根在 $340 \mathrm{~K}$ 发生歧化反应生成气相 $\mathrm{HCOOH}$ 和 $\mathrm{CO}_{2}$ 分子 $\left(2 \mathrm{HCOO}(\mathrm{a})=\mathrm{CO}_{2}+\mathrm{HCOOH}\right)$.

在0.12 ML-O(a)/Au(997)和0.26 ML-O(a)/Au(997)表面暴露0.5 L 甲酸时, 甲酸分子完全反应, 原子氧过量. 表面物种是 $\mathrm{Au}(111)$ 平台位和 $\mathrm{Au}(111)$ 台阶位吸附的甲酸根、羟基和原子氧. 在加热过程中, $\mathrm{Au}(111)$ 平台位和 $\mathrm{Au}(111)$ 台阶位的甲酸根 分别在 309 和 $340 \mathrm{~K}$ 同时发生氧化反应 $\left(\mathrm{HCOO}(\mathrm{a})+\mathrm{O}(\mathrm{a})=\mathrm{H}_{2} \mathrm{O}+\mathrm{CO}_{2}\right)$ 和歧化反应 $\left(2 \mathrm{HCOO}(\mathrm{a})=\mathrm{CO}_{2}+\mathrm{HCOOH}\right)$ 生成气相 $\mathrm{CO}_{2}, \mathrm{H}_{2} \mathrm{O}$ 和 $\mathrm{HCOOH}$ 分子.

在0.26 ML-O(a)/ $\mathrm{Au}(997)$ 表面暴露10 L 甲酸时, 甲酸分子和原子氧均未完全消耗. 表面物种是 $\mathrm{Au}(111)$ 平台位和 $\mathrm{Au}(111)$ 台阶位吸附的甲酸根、羟基、甲酸分子和原子氧. 在加热过程中, 除了上述甲酸根的氧化反应和歧化反应, 还发生 $171 \mathrm{~K}$ 的 甲酸分子与羟基的反应 $\left(\mathrm{HCOOH}(\mathrm{a})+\mathrm{OH}(\mathrm{a})=\mathrm{H}_{2} \mathrm{O}+\mathrm{HCOO}(\mathrm{a})\right.$ )和 $216 \mathrm{~K}$ 的羟基并和反应 $\left(\mathrm{OH}(\mathrm{a})+\mathrm{OH}(\mathrm{a})=\mathrm{H}_{2} \mathrm{O}+\mathrm{O}(\mathrm{a})\right.$ ).

关键词: 金催化; 表面化学; 模型催化剂; 几何结构; 配位数

收稿日期: 2016-04-11. 接受日期: 2016-05-16. 出版日期: 2016-10-05.

*通讯联系人. 电话: (0551)63600435; 传真: (0551)63600437; 电子信箱: huangwx@ustc.edu.cn

基金来源：国家重点基础研究发展计划(973计划, 2013CB933104); 国家自然科学基金(21525313, 20973161, 21373192); 中央高校 基本科研业务费专项资金(WK2060030017); 苏州纳米科学与技术协同创新中心.

本文的英文电子版由Elsevier出版社在ScienceDirect上出版(http://www.sciencedirect.com/science/journal/18722067). 